\title{
Molecular mechanisms of versatile biological activity of interleukin-7
}

\author{
A. V. Slyvka ${ }^{1}$, O. V. Okunev \\ ${ }^{1}$ Educational and Scientific Center «Institute of Biology», Taras Shevchenko National University of Kiev \\ 64/13, Volodymyrska Str., Kyiv, Ukraine, 01601 \\ ${ }^{2}$ Institute of Molecular Biology and Genetics, NAS of Ukraine \\ 150, Akademika Zabolotnoho Str., Kyiv, Ukraine, 03680 \\ antonslyvka3@gmail.com
}

\begin{abstract}
As a result of immunological studies of the last 25 years it turned out that interleukin-7 (IL-7) is one of the most important regulatory cytokines of the immune system. It is special in many concerns. Having a strong impact on the development, proliferation and activation of immune cells it is, however, cannot be attributed to the classic cytokine-activators, like IL-2, as many types of cells require its presence at almost all stages of the development, and its spectrum of activities is impressive. The review aims to summarise the numerous data obtained on the IL-7 structure, biological activity, biological significance and features of functioning studied both in vitro and in vivo. We made the main emphasis on the IL-7 signal transduction pathways that determine the fate of $T$ and $B$ cells, as well as some other cells important for homeostasis of the organism. In our opinion, the analysis of literature in this field not only reveals a host of questions still unanswered, but also makes the path for perspective investigation more visible.
\end{abstract}

Keywords: cytokine, immune system, signal transduction, regulation.

Introduction. In recent years, considerable attention has been paid to studying the mechanisms of communication between different cell types important for the integrity and homeostasis of the organism. An unusually large number of signaling molecules were discovered including their receptors and intracellular messengers involved in either the activation or suppression of various genes influencing functional behavior of the cell. All these molecules form an incredibly complicated signaling network exploiting the principles of overlapping, amplification or turning off certain signaling pathways and elements. One of the most complicated signaling networks is a cytokine signaling network.

Cytokines are special signaling glycoproteins belonging to the immune system and having molecular weight less than $30 \mathrm{kDa}$. They are released into the blood and lymph mainly by $\mathrm{T}$ cells and act at very low concentration $\left(10^{-12} \mathrm{M}\right)$.

(c) Institute of Molecular Biology and Genetics, NAS of Ukraine, 2014
However, in addition to T cells, cytokines are produced by broad range of cells, including immune cells like macrophages, B lymphocytes and mast cells, as well as endothelial cells, fibroblasts, and various stromal cells; a given cytokine may be produced by more than one type of cell [1]. In total, there are over $100 \mathrm{cy}-$ tokines, that are classified according to their functions into interferons, interleukins, colony stimulating factors, chemokines and tumor necrosis factors. It is considered that the interleukins (ILs) family comprises 37 members (IL-1-37); however, currently more than 40 cytokines are designated as ILs.

This review is dedicated to a special member of the gamma-chain cytokine family - interleukin-7 (IL-7). It was discovered at Immunex Research and Development corporation in 1988 [2]. Human cDNA was first cloned in 1989 [3]. Numerous studies revealed that IL-7 is a nonredundant hematopoetic cytokine, which plays a crucial role in the development and homeostasis of many types of immune cells. 
Here we try to encompass the latest data about the mechanisms of signal transduction that allow revealing an intricate network of interactions of IL-7 with other cytokine signaling systems. In spite of considerable information obtained on IL-7, still only few data on the role of interaction between IL-7 and other signaling molecules are available and need to be reviewed, as well as some other aspects of its biological effects.

Interleukin-7 molecular structure. Interleukin-7 is a single chain $25 \mathrm{kD}$ glycoprotein containing $4 \alpha$ helices that are internally disulfide cross-linked. Hydrophobic core of human IL-7 is formed by amino acids L16, M17, I20, L23, L24 (helix A), F55, L56, A59, L63, F66 (helix B), L79, V82, T86, L89, T93 (helix C), L128, L131, L135, I138 and W142 (helix D). As it is typical for hematopoietic cytokines, amino acid residues of side sequences are also parts of the core of the molecule. In case of IL-7 they are M27, F39, F41, F42 (loop AB) and F75 (loop BC) [4].

Human IL-7 gene is located at 8q12-q13 chromosome. The length of this gene is about $33 \mathrm{~kb}$ and it contains 6 exons and 5 introns. The protein product of the IL-7 gene has molecular weight of $17.4 \mathrm{kDa}$, but after $\mathrm{N}$-glycosilation at three sites (Asn95, Asn116 and Asn 141) it reaches $25 \mathrm{kDa}$.

IL-7 molecule contains six cysteine residues, which make three intramolecular disulphide bonds (Cys 34 Cys 129, Cys 47-Cys 141 and Cys 2-Cys 92). IL-7 molecule displays very high stability even with extreme $\mathrm{pH}$ variation (from 2.1 to 8.0) [5]. However, it loses its biological activity after the addition of $\beta$-mercaptoethanol, pointing to the importance of disulfide bonds [6]. Up to 6 isoforms have been described as the products of alternative splicing, and predictions of their structure have been generated. There are three additional in-frame splice variants, which lack exons either 3 or 5 or both and exon 4, respectively: IL-7delta3/4, IL-7delta4/5 and IL-7delta3/4/5. Also three out-of-frame splice variants were found: IL-7 (-56 bp exon 2), IL-7delta4 (-56 bp exon 2), and IL-7delta3/4/5 (-56 bp exon 2), which, besides the aforementioned exon deletions, miss $56 \mathrm{bp}$ at the 3' end of exon 2 [7]. The biological properties of IL-7 splice variants are poorly investigated.

Sites and regulation of production. Production of IL-7 has been detected in multiple stromal tissues, including the thymus and bone marrow $[8,9]$. Within the thy- mus, the predominant cell responsible for IL-7 production appears to be a major histocompatibility complex (MHC) class II + epithelial cell that likely represents a cortical epithelial cell [10]. The additional sites of IL-7 production include intestinal epithelium, keratinocytes, fetal liver, adult liver, dendritic cells and follicular dendritic cells [11-17]. Thus, IL-7 is essentially a tissuederived cytokine, with the primary sources in stromal and epithelial cells of various locations, whereas bone marrow-derived dendritic cells appear to be relatively minor sources of IL-7.

Biological effects of IL-7. Originally, IL-7 was described as a pre-B cell growth factor (lymphopoietin-1) found in the supernatant of the bone marrow-derived stromal cells [18]. However, the studies soon followed demonstrated that in vitro IL-7 was also important for mature T cell and thymocyte growth. Subsequently, in vivo studies have shown that IL-7 plays an important role in the T cell development [19], mature T cell homeostasis [20] and the development of so called lymphoid tissue inducer cells (LTi cells) [21], playing a key role in the development of lymph nodes and Peyer's patches [22]. IL-7 is also important for dendritic cells (DCs) [23] and natural killer cells (NK cells) [24]. Defciencies in IL-7 or any component of IL-7R in mice result in severely impaired $\mathrm{B}$ and $\mathrm{T}$ lymphopoiesis [25].

Interleukin-7 receptor (IL-7R). IL-7 mediates its effects via engagement of specific receptor, IL-7R - a heterodimer comprised of IL-7R $\alpha$ (also known as CD127) and the common cytokine receptor $\gamma$-chain $(\gamma \mathrm{c}$, also known as CD132), and mediates anti-apoptotic and co-stimulatory proliferative signals. As summarized in Fig. 1, IL-7-mediated signaling participates in the T cell receptor (TCR) gene rearrangement through DNA demethylation and histone acetylation during the $\mathrm{T}$ cell development in the thymus. IL-7-mediated signaling initiates downstream signaling pathways through Janus kinase 1 (Jak1), Jak3 and phosphatidylinositol-3-kinase (PI3K), resulting in phosphorylation and activation of signal transducer and activator of transcription 5 (STAT5).

This results in changes in the expression of $\mathrm{B}$ cell lym phoma 2 (Bcl-2) family members, such as increased expression of the anti-apoptotic molecules Bcl- 2 and Mcl1 (myeloid cell leukaemia sequence 1) and decreased expression of the pro-apoptotic molecules BAX 


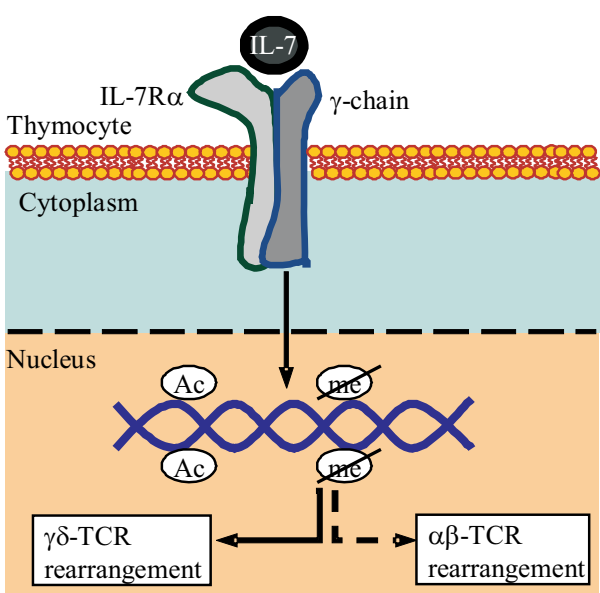

(Bcl-2-associated X protein), BIM (Bcl-2-interacting mediator of cell death) and BAD (Bcl-2 antagonist of cell death). IL-7-mediated signaling in T cells also leads to decreased levels of the cyclin-dependent kinase inhibitor p27 (also known as p27Kip1), increased levels of CDC25A (cell division cycle 25 homologue A) and changes in the expression of TCR modulators such as Casitas B-lineage lymphoma B (CBL-B). The results of IL-7me diated signaling are increased $\mathrm{T}$ cell survival, increased proliferation, augmented TCR signals and, for recent thymic emigrants, TCR-independent proliferation. In contrast to other members of the $\gamma c$ cytokine receptor family, which are upregulated upon T cell activation and/ or cytokine signaling, IL-7R $\alpha$ is expressed mostly by resting $\mathrm{T}$ cells and is downregulated following IL-7mediated signaling and/or T cell activation [26, 27].

The molecular weight of IL-7R protein is about 121 $\mathrm{kDa}$. Both IL-7R $\alpha$ and $\gamma \mathrm{c}$ have a pair of conserved extracellular cysteine residues and an extracellular Trp-Ser$\mathrm{X}$-Trp-Ser motif and lack the intrinsic tyrosine kinase activity and two partially conserved regions in the membrane-proximal part of their intracellular domains. The $\gamma c$ chain augments IL-7 binding to IL-7R $\alpha$ chain. The IL-7R $\alpha$ protein exists in two isoforms: membranebound and soluble forms. The membrane-bound isoform is also found on the cell surface in association with IL-2R $\gamma c$ [28]. Binding assays have demonstrated the presence of two IL-7 receptor affinities: a high $\left(K_{\mathrm{d}} \sim\right.$ $\left.10^{-10} \mathrm{M}\right)$ and a low $\left(K_{\mathrm{d}} \sim 10^{-8} \mathrm{M}\right)$ affinity. It has been also demonstrated that IL-7 can induce signal transduction events in cells that do not express IL-7R because of its capacity to engage other surface receptors such as Flt3 and c-kit [29].
IL-7R $\alpha$ is a transmembrane heterotypic cytokine receptor belonging to the cytokine receptor homology class 1 (CRH1) family and to the $\gamma c$ family. $\gamma$ c functions as the activating receptor for IL-2, IL-4, IL-7, IL-9, IL-15, and IL-21 [30]. Full-length human IL-7R $\alpha$ consists of a 219-residue extracellular domain (ECD), a 25-residue transmembrane domain (TMD), and a 195-residue intracellular domain (ICD) [31]. IL-7 signaling was initially thought to function via the classical stepwise cytokineinduced receptor heterodimerization way [32]. By this mechanism, IL-7 interacts with the IL-7R $\alpha$ ECD, forming a 1:1 assembly, which subsequently recruits $\gamma \mathrm{c}$, producing the signaling complex. However, the classical paradigm was questioned when IL-7R $\alpha$ homodimers and IL-7R $\alpha-\gamma c$ heterodimers were demonstrated on T cells in the absence of IL-7. Neither the preassembly of IL-7R $\alpha$ homodimers nor IL-7R $\alpha-\gamma$ c heterodimers induced signaling [33].

IL-7R ligand binding. IL-7R $\alpha$ homodimer consists of two IL-7R $\alpha$ molecules packed against each other with pseudotwofold symmetry (Fig. 2). This structure explains why homodimerization of IL-7R $\alpha$ does not activate either IL-7 or TSLP signaling pathways. The average distance between the $\mathrm{C}$-terminal domains of the $\alpha / \beta$ receptors and $\gamma_{c}$ is $27 \AA$. Similar distance between the $\mathrm{C}$ terminal domains of IL-7R $\alpha$ and $\gamma c$ in an activating complex was predicted. However, the distance between the $\mathrm{C}$-terminal domains of the homodimeric IL-7R $\alpha$ structure is $110 \AA$. It means that the Jak1 molecules bound to the IL-7R $\alpha$ ICDs are not able to activate each other because of the distance between them. The investigations demonstrated a stronger binding affnity between the fulllength IL-7R $\alpha$ and $\gamma c$ than between the IL-7R $\alpha$ in a ho- 


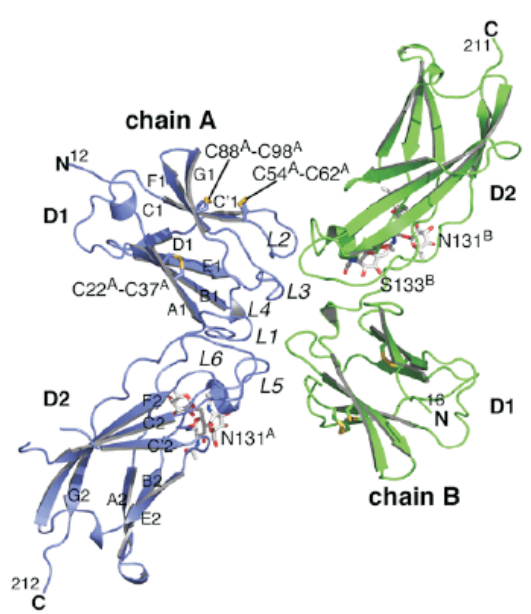

Fig. 2. Ribbon diagram of the IL-7R $\alpha$ homodimer oriented looking down onto the cell surface. Chains A and B are colored purple and green, respectively. The six loop regions involved in the interface and ligand binding are labeled L1-L6 [34]

modimer on $\mathrm{T}$ cells at $37^{\circ} \mathrm{C}$ [33]. The following studies showed that there is a stronger binding affnity for heterodimerization of the IL-7R $\alpha-\gamma \mathrm{c}$ ECDs than for homodimerization of the IL-7R $\alpha$ ECDs $\left(\mathrm{K}_{\mathrm{d}}\right.$ of $3.1 \mu \mathrm{M} v s>$ $610 \mu \mathrm{M}$ at $\left.25^{\circ} \mathrm{C}\right)[34]$.

As it has been already stated, the IL-7R $\alpha$ homodimer keeps the Jak1 molecules bound to the ICDs separated by $110 \AA$. Likewise, the IL-7R $\alpha-\gamma c$ heterodimer would keep Jak1 and Jak3 separated by a large distance preventing activation. When IL-7 binds both IL-7R $\alpha$ and $\gamma \mathrm{c}$, the receptors undergo $90^{\circ}$ rotation away from the cell surface, bringing the two C termini of IL-7R $\alpha$ and $\gamma \mathrm{c}$ at a distance less than $30 \AA$ and activating signal transduction [34].

The spontaneously formed 1:1 heterodimers of IL$7 \mathrm{R}$ and $\gamma \mathrm{c}$ (1:1 stoichiometry) at the surface of living human $\mathrm{CD}^{+} \mathrm{T}$ cells in the absence of IL-7 also were described. IL-7R $\alpha$ is abundant on the resting human $\mathrm{CD} 4^{+} \mathrm{T}$ cells $\left(108 \mathrm{pmol} / \mathrm{m}^{2}\right)$, but $\gamma \mathrm{c}$ is present at low concentrations $\left(12 \mathrm{pmol} / \mathrm{m}^{2}\right)$ and thus restricts the heterodimer formation $\left(10 \mathrm{pmol} / \mathrm{m}^{2}\right)$ [35]. The heterodimer has a dissociation constant $K_{\mathrm{d}}$ of $19 \mathrm{pmol} / \mathrm{m}^{2}$ which is greater than the $\gamma c$ chain concentration. This explains why $80 \%$ of $\gamma \mathrm{c}$ are found in the bound state in cultures of living cells $[36,37]$. The affinity of IL-7R $\alpha$ to $\gamma c$ is $17-$ fold greater than to itself, meaning that formation of the heterodimer is largely favored and does not limit $\gamma \mathrm{c}$ binding. Both heterodimers and homodimers coexist in resting cells [34].
The receptor complex compartmentalizes after IL-7 binding. Interestingly, about $70 \%$ of the proteins recruited upon IL-7 binding belong to the the cytoskeleton or are associated with lipid rafts. IL-7 binding drives receptor complex into lipid rafts. By the other probable mechanism lipid rafts are formed around the receptor. The IL-7-IL-7R complex consequently recruits proteins for the construction of the signaling complex. These recruited proteins are FERM proteins (ezrin, radixin, moesin) that anchor the rafted receptor complex to the cytoskeleton to prevent its diffusion. As far as the lipid rafts are rich in cholesterol and sphingomyelin, the membrane thickness is increased. This helps to hold the long transmembrane domain straight, which in turn keeps the juxtaposition of the cytoplasmic domains. The lateral diffusion of lipids and embedded proteins is reduced by the network of hydrogen bonds between cholesterol and sphingomyelin and this prolongs IL7-IL-7R association, what is essential for the signaling [38]. The cytoskeleton provides a scaffold for movement of signaling proteins involving complicated machineries to dispatch signaling molecules to their targets.

IL-7R signaling. Jak/STAT and Src activation. As it was said, the binding of IL-7 to the IL-7R leads to dimerization of $\alpha$ and $\gamma \mathrm{c}$ chains, which brings Jak1 and Jak3 in close proximity and allows for trans-phosphorylation, resulting in the increased kinase activity. Activated Jak kinases phosphorylate tyrosine residues of the IL-7R $\alpha$ chain ICD that in turn creates docking sites for SH2 containing proteins. Jak $3^{---}$or the $\gamma \mathrm{c}^{-/-}$knock-out mice have similar phenotypes as well as IL- $7^{-/-}$or the $\mathrm{IL}^{-7 \mathrm{R}^{-/}}$knock-out mice. Mutations in Jak3 or the $\gamma \mathrm{c}$ chain in humans lead to a T-NK-B ${ }^{+}$SCID phenotype [39, 40]. Jak $1^{-/}$mice exhibit a severe reduction of $\mathrm{T}$ and $\mathrm{B}$ cells, are runt at birth, and die perinatally [41]. IL-7R $\alpha$ phosphorylation is crucial for initiating down-stream signaling as it leads to the recruitment of STAT proteins to these phosphorylated residues. Phosphorylation of the STAT proteins allows them to dimerize and translocate to the nucleus where they act as transcription factors by binding to specific promoters [42]. The STAT family includes seven STAT proteins (STAT 1-4, 5a, 5b and STAT6). Only STAT1, STAT3, STAT5a and STAT5b take part in IL-7 signaling $[43,44]$. STAT1 does not play a direct role in lymphopoiesis but STAT3 is required, because a serious reduction in pro-B, pre- $\mathrm{B}$, immature 
and mature B cells, and pro-B cells was observed in $\mathrm{STAT3}^{--}$mice. Additionally, these mice exhibited a decrease in proliferative responses to IL-7 [43]. STAT5 is the main STAT protein activated by IL-7 and mediates most of the responses of Jak/STAT pathway in cells, including the activation of ccnd2, ccnd3, Bcl-2, Bcl-xL, and Mcl-1 $[45,46]$. STAT5 is recruited to phoshorylated Tyr449 of the IL-7R $\alpha$ chain where it is subsequently phosphorylated by Jak and Src kinases. STAT5a and STAT $5 b$ are absolutely essential for thcell development. This was proved by using STAT5a/b double deficient mice, which have been arrested at the pre-pro-B cell stage. IL-7R $\mathrm{R}^{--}$mice had similar phenotype [47]. Moreover, the constitutive activation of STAT5b in IL-7 $\mathrm{R}^{-/}$mice significantly increased pro-B cells [48]. The use of Rag1Cre knock-in mice for conditional mutagenesis of STAT5 in B cells led to complete inactivation of STAT5 which caused severe defects in the further development of B cells [49]. IL-7 binding also recruits Src kinases to IL$7 \mathrm{R} \alpha$ including both p59fyn and p53lyn. The Src kinase inhibitors are shown to be involved in impaired proliferative responses to IL-7 [50]. The Src family kinases play redundant roles during the $\mathrm{B}$ cell development and their function in IL-7 signaling has yet to be fully elucidated. One potential role is to help to activate the STAT proteins, because Src kinases can directly phosphorylate the STAT proteins independently or in conjunction with the Jak proteins [51].

PI3K/Akt and MAPK/Erk pathways. IL-7 binding to its receptor also leads to activation of phosphatidylinositol 3-kinase (PI3K). PI3K is a heterodimeric protein built of two subunits: catalytic subunit (p110 $\alpha, \mathrm{p} 110 \beta$ or $\mathrm{p} 110 \delta$ ) and regulatory subunit (p50 $\alpha, \mathrm{p} 55 \alpha$ or $\mathrm{p} 85 \alpha$ ). $\mathrm{P} 85 \alpha$ of $\mathrm{PI} 3 \mathrm{~K}$ is also $\mathrm{SH} 2$ containing protein which is recrutred to phosphorylated Tyr449 of IL-7R $\alpha$ [52]. Mutations of Tyr499 or the $\mathrm{p} 85$ subunit, as well as use of the PI3K inhibitors, resulted in a loss of the IL-7-induced proliferation and impaired the B cell development [53-55]. The $\mathrm{p} 110 \alpha^{-/-}$and $\mathrm{p} 110 \alpha^{-/}$double deficient mice were arrested at the pre-B cell stage, but showed less impaired proliferative responses to IL-7, which means that the $\mathrm{p} 110 \alpha$ and $\mathrm{p} 110 \alpha$ subunits play essential but redundant roles during $\mathrm{B}$ lymphopoiesis [56].

The most important downstream mediator of PI3K is serine/threonine kinase Akt (PKB). Akt regulates a large number of pro- and anti-apoptotic factors. One of the important targets of Akt is the Forkhead box (FoxO) family of transcription factors (TFs) [57]. Akt phosphorylates the FoxO proteins which in turn bind 14-3-3 proteins. The phosphorylation retains them in the cytosol where they are unable to regulate the gene transcription. Akt regulates cell survival inducing Bcl-2 and Bcl-xL, and inhibiting Bad by phosphorylating it and causing it to be retained in the cytosol where it remains inactive [58].

IL-7R signaling also involves the MAPK/Erk pathway. Treatment of pre-B cells with Erk inhibitors as well as deletion of Erk $1 / 2$ in mice blocked the pro-B to pre-B cell transition and caused a decreased IL-7-induced pro-B/pre-B cell survival and proliferation. This means that Erk is an extremely important molecule in IL-7 responses [54, 57]. Activated Erk proteins translocate to the nucleus where they phosphorylate a variety of TFs including Elk and CREB, which in turn induce the expression of proliferation associated targets 1lf2, Mef2c, Mef2d and myc [59]. The adaptor protein Shc also may be an important mediator in MAPK/Erk pathway because the pro-B cells containing a defective Shc protein displayed an increased apoptosis level $[60,61]$.

IL-7/Jak3/NFATc1 signaling pathway. As it was mentioned, there are a variety of signaling pathways mediating the IL-7 influence on cells. These include Jak/ STAT, PI3K/Akt, MAPK/Erk signaling pathways and there are a huge number of molecules involved in signal transduction. For instance, the Jak1 and Jak3/STAT5 signaling pathway leads to production of the effector molecules, such as Bcl-2, which are crucial for T and B cell progression and proliferation (Fig. 1). The IL-7STAT5 pathway is the only critical pathway of the preTCR development of $T$ cells in the thymus $[62,63]$. However, recently Patra et al. identified the alternative IL-7/NFATc1 pathway that cooperates with the IL-7/ STAT5 during the thymocyte development [64].

IL-7 signaling was found to activate NFATc1 and facilitate its translocation to the nucleus, which was independent of STAT5 but dependent on the Tyr371 phosphorylation of Jak3. NFATc1 is a member of the NFAT family of transcription factors. NFATc1 is a lymphoidspecific factor involved in the differentiation and function of T cells. NFATc1 increases Bcl-2 expression by cooperating with STAT5, which in turn affects the survival of thymocytes [65]. 
Negative regulators of $I L-7$ signaling. There are multiple mechanisms of downregulation of IL-7 signaling, including phosphatases, cytokine-inducible inhibitor molecules, transcriptional suppressors and STAT degradation. They are necessary for termination of the signaling of overactive cytokines to prevent autoimmunity or tumourigenicity. SHP-1 is one of the negative regulators of cytokine signaling [66]. SHP-1 can dephosphorylate both Jaks as well as activated receptor subunits, depending on the pathway activated [67]. SOCS-1 and CIS-1 have also been identified as suppressors of cytokine signaling [68]. For instance, SOCS-1 (suppressor of cytokine signaling proteins-1) can inhibit Jak-kinases due to the binding of phosphorylated tyrosine residues. The cytokine inducible src homology-2 protein (CIS) binds directly to the activated IL-7R. The protein inhibitors of activated STATs (PIAS) are proposed to inactivate STATs. Subsequently, several other members of inhibitors were found (CIS2-CIS7/ SOCS2-SOCS7) $[68,69]$. Bcl-6 also can bind the STAT docking site on the receptor ICD and repress the signaling. Additionally, CIS/CIS1 negatively regulates STAT5 activation [70]. Inhibition of the downstream signaling of Jaks has been shown to abrogate constitutive STAT3 DNA binding, inhibit cell proliferation and induce apoptosis in human breast carcinoma cell lines. Moreover, the expression of dominant negative STAT3 in these cells induces growth arrest and apoptosis [71]. The degradation of STAT is another way by which the Jak-STAT pathway can be negatively regulated [72]. The accumulation of STATs in the nucleus can also be regulated at the level of nuclear import or/and export [42]. The mechanisms that control these processes are not completely understood.

IL-7R $\alpha$ regulation. One of the most important mechanisms of regulation of IL-7 signaling is the regulation of the amount of its receptor alpha chain (IL-7R $\alpha$ ) present on the surface of the IL-7 dependent cells, as far as the level of IL-7R $\alpha$ directly correlates with the cell sensitivity to IL-7. The consumption of IL-7 is strictly controlled by IL-7-induced downregulation of IL-7R $\alpha$, because of the limiting amount of available IL-7. This downregulation allows maximizing the total number of the cells which can receive proliferative and survival signals of IL-7 [73]. In the absence of IL-7 signaling, IL-7R $\alpha$ expression on the cell surface is regulated by ephrin molecules (Efn). The deletion of ephrin genes in T cells, particularly Efnb1 and Efnb2, leads to a decreased peripheral naive $\mathrm{T}$ cell compartment size. These Efns stabilize IL-7R $\alpha$ expression on T cells interacting directly with IL-7R $\alpha$ [74]. In Efnb1/Efnb2 double deficient $\mathrm{T}$ cells upon IL-7 stimulation it was observed a stronger downregulation of IL-7R $\alpha$, as well as a decreased STAT5 phosphorylation level. Upon IL-7 stimulation, IL-7R $\alpha$ expression on the cell surface is downregulated. Although IL-7R $\alpha$ regulation occurs at the transcriptional level by multiple mechanisms, it is also regulated at the post-translational level. IL-7R $\alpha$ does not persist stably at the cell surface in the absence of IL-7, but is rather constantly endocytosed via the clathrincoated pits and recycled back to the plasma membrane [75]. In the absence of IL-7, only a fraction of IL-7R $\alpha$ is degraded through the proteasomal and lysosomal pathway, with the rest recycled back to the plasma membrane. Upon IL-7 stimulation, the degradation/recycling ratio is inverted in favor of degradation, leading to a decreased surface expression of IL-7R $\alpha$ [75]. Such an increased degradation is dependent on the Jak-3 activity and it concerns only IL-7R $\alpha$, but not the $\gamma c$, as it was shown by the studies with the human lymphoma $\mathrm{T}$ cell line $[75,76]$.

Soluble IL-7R. Additonally to relatively well described membrane-bound cytokine receptors there are soluble forms of many of them. The functions of soluble receptors are definitely less understood but they are known to play an essential role in cytokine biology [77]. Soluble IL-7R $\alpha$ (sIL-7R $\alpha$ ) circulates at high concentration $(\mathrm{nmol} / \mathrm{mL})$ compared to IL-7 in healthy humans (pmol/mL) [78]. Besides, the biologic effects of sIL7R $\alpha$ remain unclear. The biochemical studies show ed that sIL7R $\alpha$ is derived from alternative splicing and comprises an isoform lacking exon $6(\Delta 6 \mathrm{IL}-7 \mathrm{R} \alpha)$ and having a unique 26-aa sequence [31]. Soluble IL-7R $\alpha$ was reported to block IL-7 signaling. In these studies it was used the IL-7R $\alpha-\mathrm{Fc}$ fusion protein, consisting of the ECD of IL7R $\alpha$ and human Fc-fragment, which has a lower affinity to IL-7 than native sIL-7R $\alpha$. However, the coadministration of the same molecule, IL7R $\alpha-\mathrm{Fc}$, with IL-7 enhanced antitumor effects compared with the administration of IL-7 alone in the immunotherapy model of lung cancer in mice [79]. Complexing IL-7 to anti-IL-7 mAb also enhanced the potency of IL-7 in 
murine models $[80,81]$. The next studies have shown that the competition between IL-7R and sIL-7R $\alpha$ serves to make IL-7 available for all cells according to their needs. This is possible because sIL-7R $\alpha$ binds IL-7 with nanomolar affinity, whereas IL-7R binds it with picomolar affinity. That is why sIL-7R $\alpha$ diminishes the availability of free IL-7 and modestly compete with cell-associated IL7R. This results in decreased early signaling, as evidenced by diminished STAT5 phosphorylation, but also leads to IL-7 consumption, leading in turn to overall more enhanced IL-7 effects in the cells which have limited amounts of IL-7. The coadministration of sIL7R $\alpha$ plus IL-7 increased the half-life of IL-7 in vivo, increased IL-7-mediated homeostatic peripheral expansion of lymphocytes during lymphopenia, and worsened the severity of experimental autoimmune encephalitis compared with that in mice receiving IL-7 alone. Howewer, the administration of sIL-7R $\alpha$ alone in the same model had no effect [82]. Thus, the experimental data suggest that sIL-7R $\alpha$ plays the role of a carrier protein, and that the binding of IL-7 to it potentiates the biological activity of IL-7.

Conclusions. The review aims to summarize numerous data on the cytokine IL-7 structure, biological activity, biological significance and features of functioning studied both in vitro and in vivo. We have made the main emphasis on the IL-7 potential and conditions to govern the activity of the appropriate signal transduction pathways that determine the fate of $\mathrm{T}$ and $\mathrm{B}$ cells, as well as LTi cells, NK cells and DCs, which are extremely essential for the development of immunological reactions of the organism. In our opinion, the literature analysis in this field reveals a host of questions remained unanswered so far, and also makes the path for perspective investigation more visible.

Aknowlegements. We thank Dr. Elena Cherepenko for careful review of this manuscript and helpful discussions.

Молекулярні механізми багатосторонньої біологічної активності інтерлейкіну-7

А. В. Сливка, О. В. Окунєв

Резюме

У результаті імунологічних досліджень останніх 25 років показано, щьо інтерлейкін-7 (ІЛ-7) є одним з найважливіших регуляторних ицитокінів імунної системи. Він чинить значний вплив на розвиток, проліферацію і активацію імунних клітин, однак не належить до класичних цчитокінів-активаторів, як, наприклад, IЛ2, оскільки багато типів клітин потребують його присутності майже на всіх стадіях розвитку, а спектр його активностей $\epsilon$ вражаючим. Цей огляд має на меті узагальнити численні дані щодо структури IЛ-7, його біологічної активності $і$ особливостей функціонування in vitro ma in vivo. Основний акцент зроблено на шляхах сигнальної трансдукиії IЛ-7, які визначають долю Tі В-клітин, а також деяких інших клітин, важливих для підтримання гомеостазу організму. Аналіз літератури циієі сфери, на наиу думку, не лите виявив низку питань, які наразі не мають відповідей, але й окреслив напрямки для майбутніх досліджень.

Ключові слова: ичитокін, імунна система, сигнальна трансдукиія, регулячія.

Молекулярные механизмы многосторонней биологической активности интерлейкина-7

\section{А. В. Сливка, О. В. Окунев}

Резюме

В результате иммунологических исследований последних 25 лет показано, что интерлейкин-7 (ИЛ-7) является одним из важнейших регуляторных цитокинов иммунной системы. Он оказывает значительное влияние на развитие, пролиферачию и активачию иммунных клеток, онднако не принадлежит к классическим цитокинам-активаторам, как, например, ИЛ-2, поскольку много типов клеток нуждаются в его присутствии почти на всех стадиях своего развития, а спектр его активностей впечатляет. Цель этого обзора состояла в обощении многочисленных данных по структуре ИЛ-7, его биологической активности и особенностям функиионирования in vitro $и$ in vivo. Основной акцент сделан на путях сигнальной трансдукции ИЛ-7, определяющих судьбу Ти В-клеток, а также некоторых других клеток, важных для поддержания гомеостаза организма. Анализ литературы этой сфеpbl, по нашему мнению, не только выявил ряд вопросов, на которые до сих пор нет ответов, но и очертил направления для будуших исследований.

Ключевые слова: ичитокин, иммунная система, сигнальная трансдукиия, регуляиия.

\section{REFERENCES}

1. Akdis M, Burgler S, Crameri R, et al. Interleukins, from 1 to 37 , and interferon- $\gamma$ : receptors, functions, and roles in diseases. $J \mathrm{Al}$ lergy Clin Immunol. 2011;127(3):701-21.e1-70.

2. Namen AE, Lupton $S$, Hjerrild K, et al. Stimulation of B-cell progenitors by cloned murine interleukin-7. Nature. 1988;333 (6173):571-3.

3. Namen AE, Schmierer AE, March CJ, et al. B cell precursor growth-promoting activity. Purification and characterization of a growth factor active on lymphocyte precursors. J Exp Med. 1988;167(3):988-1002.

4. Kroemer RT, Doughty SW, Robinson AJ, Richards WG. Prediction of the three-dimensional structure of human interleukin-7 by homology modeling. Protein Eng. 1996;9(6):493-8.

5. Costello R, Imbert J, Olive D. Interleukin-7, a major T-lymphocyte cytokine. Eur Cytokine Netw. 1993;4(4):253-62.

6. Appasamy PM. Interleukin-7: biology and potential clinical applications. Cancer Invest. 1993;11(4):487-99. 
7. Vudattu NK, Magalhaes I, Hoehn H, Pan D, Maeurer MJ. Expression analysis and functional activity of interleukin-7 splice variants. Genes Immun. 2009;10(2):132-40.

8. Wiles $M V$, Ruiz $P$, Imhof $B A$. Interleukin-7 expression during mouse thymus development. Eur J Immunol. 1992;22(4):1037-42.

9. Sakata T, Iwagami S, Tsuruta Y, et al. Constitutive expression of interleukin-7 mRNA and production of IL-7 by a cloned murine thymic stromal cell line. J Leukoc Biol. 1990;48(3):205-12.

10. Oosterwegel MA, Haks MC, Jeffry U, Murray R, Kruisbeek AM. Induction of TCR gene rearrangements in uncommitted stem cells by a subset of IL-7 producing, MHC class-II-expressing thymic stromal cells. Immunity. 1997;6(3):351-60.

11. Madrigal-Estebas L, McManus R, Byrne B, et al. Human small intestinal epithelial cells secrete interleukin-7 and differentially express two different interleukin-7 mRNA Transcripts: implications for extrathymic T-cell differentiation. Hum Immunol. 1997; 58(2):83-90.

12. Heufler C, Topar G, Grasseger A, et al. Interleukin 7 is produced by murine and human keratinocytes. J Exp Med. 1993;178 (3):1109-14.

13. Gutierrez-Ramos JC, Olsson C, Palacios R. Interleukin (IL1 to IL7) gene expression in fetal liver and bone marrow stromal clones: cytokine-mediated positive and negative regulation. Exp Hematol. 1992;20(8):986-90.

14. Golden-Mason L, Kelly AM, Traynor $O$, et al. Expression of interleukin 7 (IL-7) mRNA and protein in the normal adult human liver: implications for extrathymic T cell development. $C y$ tokine. 2001;14(3):143-51.

15. de Saint-Vis B, Fugier-Vivier I, Massacrier C, et al. The cytokine profile expressed by human dendritic cells is dependent on cell subtype and mode of activation. J Immunol. 1998;160(4):1666-76.

16. Sorg RV, McLellan AD, Hock BD, Fearnley DB, Hart DN. Human dendritic cells express functional interleukin-7. Immunobiology. 1998;198(5):514-26.

17. Kroncke R, Loppnow H, Flad HD, Gerdes J. Human follicular dendritic cells and vascular cells produce interleukin-7: a potential role for interleukin-7 in the germinal center reaction. Eur $J$ Immunol. 1996;26(10):2541-4.

18. Namen AE, Schmierer AE, March CJ, et al. B cell precursor growth-promoting activity. Purification and characterization of a growth factor active on lymphocyte precursors. J Exp Med. 1988; 167(3):988-1002.

19. Peschon JJ, Morrissey PJ, Grabstein KH, et al. Early lymphocyte expansion is severely impaired in interleukin 7 receptor-deficient mice. J Exp Med. 1994;180(5):1955-60.

20. Schluns KS, Kieper WC, Jameson SC, Lefrancois L. Interleukin-7 mediates the homeostasis of naive and memory CD8 T cells in vivo. Nat Immunol. 2000;1(5):426-32.

21. Meier D, Bornmann C, Chappaz S, et al. Ectopic lymphoid-organ development occurs through interleukin 7-mediated enhanced survival of lymphoid-tissue-inducer cells. Immunity. 2007;26 (5):643-54.

22. Puel A, Ziegler SF, Buckley RH, Leonard WJ. Defective IL7R expression in $\mathrm{T}(-) \mathrm{B}(+) \mathrm{NK}(+)$ severe combined immunodeficiency. Nat Genet. 1998;20(4):394-7.

23. Vogt TK, Link A, Perrin J, Finke D, Luther SA. Novel function for interleukin-7 in dendritic cell development. Blood. 2009;113 (17):3961-8.

24. Ribeiro VS, Hasan M, Wilson A, et al. Cutting edge: Thymic NK cells develop independently from T cell precursors. J Immunol. 2010;185(9):4993-7.

25. Treanor LM, Zhou S, Janke L, et al. Interleukin-7 receptor mutants initiate early $\mathrm{T}$ cell precursor leukemia in murine thymo- cyte progenitors with multipotent potential. J Exp Med. 2014; 211(4):701-13.

26. Park JH, Yu Q, Erman B, et al. Suppression of IL7Ralpha transcription by IL-7 and other prosurvival cytokines: a novel mechanism for maximizing IL-7-dependent T cell survival. Immunity. 2004;21(2):289-302.

27. Mackall CL, Fry TJ, Gress RE. Harnessing the biology of IL-7 for therapeutic application. Nat Rev Immunol. 2011;11(5):330-42.

28. Venkitaraman AR, Cowling RJ. Interleukin 7 receptor functions by recruiting the tyrosine kinase p59fyn through a segment of its cytoplasmic tail. Proc Natl Acad Sci US A. 1992;89(24):12083-7.

29. Cosenza L, Gorgun $G$, Urbano A, Foss F. Interleukin-7 receptor expression and activation in nonhaematopoietic neoplastic cell lines. Cell Signal. 2002;14(4):317-25.

30. Goodwin RG, Friend D, Ziegler SF, et al. Cloning of the human and murine interleukin-7 receptors: demonstration of a soluble form and homology to a new receptor superfamily. Cell. 1990; 60(6):941-51.

31. Rose T, Lambotte O, Pallier C, Delfraissy JF, Colle JH. Identification and biochemical characterization of human plasma soluble IL-7R: lower concentrations in HIV-1-infected patients. J Immunol. 2009;182(12):7389-97.

32. Rose $T$, Pillet AH, Lavergne $V$, et al. Interleukin-7 compartmentalizes its receptor signaling complex to initiate CD4 T lymphocyte response. J Biol Chem. 2010;285(20):14898-908.

33. Pillet AH, Lavergne V, Pasquier V, Gesbert F, Theze J, Rose T. IL-2 induces conformational changes in its preassembled receptor core, which then migrates in lipid raft and binds to the cytoskeleton meshwork. J Mol Biol. 2010;403(5):671-92.

34. McElroy CA, Holland PJ, Zhao P, et al. Structural reorganization of the interleukin-7 signaling complex. Proc Natl Acad Sci US A. 2012;109(7):2503-8.

35. Perna SK, Savoldo B, Dotti G. Genetic modification of cytotoxic T lymphocytes to express cytokine receptors. Methods $\mathrm{Mol}$ Biol. 2014;1139:189-200.

36. Hage T, Sebald $W$, Reinemer $P$. Crystal structure of the interleukin-4/receptor alpha chain complex reveals a mosaic binding interface. Cell. 1999;97(2):271-81.

37. Wickham J Jr, Walsh ST. Crystallization and preliminary X-ray diffraction of human interleukin-7 bound to unglycosylated and glycosylated forms of its alpha-receptor. Acta Crystallogr Sect F Struct Biol Cryst Commun. 2007;63(Pt 10):865-9.

38. Stroud RM, Wells JA. Mechanistic diversity of cytokine receptor signaling across cell membranes. Sci STKE. 2004;2004(231):re7.

39. Puel A, Ziegler SF, Buckley RH, Leonard WJ. Defective IL7R expression in $\mathrm{T}(-) \mathrm{B}(+) \mathrm{NK}(+)$ severe combined immunodeficiency. Nat Genet. 1998;20(4):394-7.

40. Macchi P, Villa A, Giliani S, et al. Mutations of Jak-3 gene in patients with autosomal severe combined immune deficiency (SCID). Nature. 1995;377(6544):65-8.

41. Nosaka T, van Deursen JM, Tripp RA, et al. Defective lymphoid development in mice lacking Jak3. Science. 1995;270(5237): 800-2.

42. Paukku K, Silvennoinen $O$. STATs as critical mediators of signal transduction and transcription: lessons learned from STAT5. Cytokine Growth Factor Rev. 2004;15(6):435-55.

43. Chou WC, Levy DE, Lee CK. STAT3 positively regulates an early step in B-cell development. Blood. 2006;108(9):3005-11.

44. van der Plas DC, Smiers F, Pouwels K, Hoefsloot LH, Lowenberg $B$, Touw IP. Interleukin-7 signaling in human B cell precursor acute lymphoblastic leukemia cells and murine BAF3 cells involves activation of STAT1 and STAT5 mediated via the interleukin-7 receptor alpha chain. Leukemia. 1996;10(8):1317-25. 
45. Heltemes-Harris LM, Willette MJ, Vang KB, Farrar MA. The role of STAT5 in the development, function, and transformation of B and T lymphocytes. Ann N Y Acad Sci. 2011;1217:18-31.

46. Mandal $M$, Powers SE, Ochiai $K$, et al. Ras orchestrates exit from the cell cycle and light-chain recombination during early B cell development. Nat Immunol. 2009;10(10):1110-7.

47. Cui $Y$, Riedlinger $G$, Miyoshi $K$, et al. Inactivation of Stat5 in mouse mammary epithelium during pregnancy reveals distinct functions in cell proliferation, survival, and differentiation. $\mathrm{Mol}$ Cell Biol. 2004;24(18):8037-47.

48. Goetz CA, Harmon IR, O'Neil JJ, Burchill MA, Farrar MA. STAT5 activation underlies IL 7 receptor-dependent B cell development. J Immunol. 2004;172(8):4770-8

49. Malin S, McManus $S$, Cobaleda $C$, et al. Role of STAT5 in controlling cell survival and immunoglobulin gene recombination during pro-B cell development. Nat Immunol. 2010;11(2):171-9.

50. Isaksen DE, Baumann H, Zhou B, et al. Uncoupling of proliferation and Stat5 activation in thymic stromal lymphopoietinmediated signal transduction. J Immunol. 2002;168(7):3288-94.

51. Ingley E, Klinken SP. Cross-regulation of JAK and Src kinases. Growth Factors. 2006;24(1):89-95.

52. Venkitaraman AR, Cowling $R J$. Interleukin-7 induces the association of phosphatidylinositol 3-kinase with the alpha chain of the interleukin-7 receptor. Eur J Immunol. 1994;24(9):2168-74.

53. Corcoran AE, Smart FM, Cowling RJ, Crompton T, Owen MJ, Venkitaraman AR. The interleukin-7 receptor alpha chain transmits distinct signals for proliferation and differentiation during B lymphopoiesis. EMBO J. 1996;15(8):1924-32.

54. Fleming $H E$, Paige $C J$. Pre-B cell receptor signaling mediates selective response to IL-7 at the pro-B to pre-B cell transition via an ERK/MAP kinase-dependent pathway. Immunity. 2001;15 (4):521-31.

55. Suzuki H, Terauchi Y, Fujiwara M, et al. Xid-like immunodeficiency in mice with disruption of the p85alpha subunit of phosphoinositide 3-kinase. Science. 1999;283(5400):390-2.

56. Ramadani F, Bolland DJ, Garcon F, et al. The PI3K isoforms p110alpha and p110delta are essential for pre-B cell receptor signaling and B cell development. Sci Signal. 2010;3(134):ra60.

57. Baracho GV, Miletic AV, Omori SA, Cato MH, Rickert RC. Emergence of the PI3-kinase pathway as a central modulator of normal and aberrant B cell differentiation. Curr Opin Immunol. 2011;23(2):178-83.

58. Downward J. PI 3-kinase, Akt and cell survival. Semin Cell Dev Biol. 2004;15(2):177-82.

59. Yasuda T, Sanjo H, Pages $G$, et al. Erk kinases link pre-B cell receptor signaling to transcriptional events required for early $\mathrm{B}$ cell expansion. Immunity. 2008;28(4):499-508.

60. Zhang L, Camerini V, Bender TP, Ravichandran KS. A nonredundant role for the adapter protein Shc in thymic $\mathrm{T}$ cell development. Nat Immunol. 2002;3(8):749-55.

61. Giles AJ, Bender TP, Ravichandran KS. The adaptor protein Shc plays a key role during early B cell development. J Immunol. 2009;183(9):5468-76.

62. Hsu HC, Mountz JD. Metabolic syndrome, hormones, and maintenance of T cells during aging. Curr Opin Immunol. 2010;22 (4):541-8

63. Hong C, Luckey MA, Park JH. Intrathymic IL-7: the where, when, and why of IL-7 signaling during T cell development. Semin Immunol. 2012;24(3):151-8.

64. Patra AK, Avots A, Zahedi RP, et al. An alternative NFAT-activation pathway mediated by IL-7 is critical for early thymocyte development. Nat Immunol. 2013;14(2):127-35.
65. Macian $F$. NFAT proteins: key regulators of T-cell development and function. Nat Rev Immunol. 2005;5(6):472-84

66. Klingmuller $U$, Lorenz U, Cantley LC, Neel BG, Lodish HF. Specific recruitment of SH-PTP1 to the erythropoietin receptor causes inactivation of JAK2 and termination of proliferative signals. Cell. 1995;80(5):729-38.

67. Ortmann RA, Cheng T, Visconti R, Frucht DM, O'Shea JJ. Janus kinases and signal transducers and activators of transcription: their roles in cytokine signaling, development and immunoregulation. Arthritis Res. 2000;2(1):16-32.

68. Yoshimura A, Ohkubo T, Kiguchi T, et al. A novel cytokine-inducible gene CIS encodes an $\mathrm{SH}$ 2-containing protein that binds to tyrosine-phosphorylated interleukin 3 and erythropoietin receptors. EMBO J. 1995;14(12):2816-26.

69. Hilton DJ, Richardson RT, Alexander WS, et al. Twenty proteins containing a C-terminal SOCS box form five structural classes. Proc Natl Acad Sci U S A. 1998;95(1):114-9.

70. Matsumoto A, Masuhara M, Mitsui K, et al. CIS, a cytokine inducible SH2 protein, is a target of the JAK-STAT5 pathway and modulates STAT5 activation. Blood. 1997;89(9):3148-54.

71. Chung CD, Liao J, Liu B, et al. Specific inhibition of Stat3 signal transduction by PIAS3. Science. 1997;278(5344):1803-5.

72. Heinrich PC, Behrmann I, Muller-Newen G, Schaper F, Graeve $L$. Interleukin-6-type cytokine signalling through the gp 130/Jak/ STAT pathway. Biochem J. 1998;334 (Pt 2):297-314.

73. Park JH, Yu Q, Erman B, et al. Suppression of IL7Ralpha transcription by IL-7 and other prosurvival cytokines: a novel mechanism for maximizing IL-7-dependent T cell survival. Immunity. 2004;21(2):289-302.

74. Luo H, Charpentier T, Wang X, et al. Efnb1 and Efnb2 proteins regulate thymocyte development, peripheral $\mathrm{T}$ cell differentiation, and antiviral immune responses and are essential for interleukin-6 (IL-6) signaling. J Biol Chem. 2011;286(48):41135-52.

75. Henriques CM, Rino J, Nibbs RJ, Graham GJ, Barata JT. IL-7 induces rapid clathrin-mediated internalization and JAK3-dependent degradation of IL-7Ralpha in T cells. Blood. 2010;115 (16):3269-77.

76. Hemar A, Subtil A, Lieb M, Morelon E, Hellio R, Dautry-Varsat $A$. Endocytosis of interleukin 2 receptors in human $\mathrm{T}$ lymphocytes: distinct intracellular localization and fate of the receptor alpha, beta, and gamma chains. J Cell Biol. 1995;129(1):55-64.

77. Heaney $M L$, Golde DW. Soluble cytokine receptors. Blood. 1996;87(3):847-57.

78. Janot-Sardet C, Assouline B, Cheynier R, Morre M, Beq S. A validated assay to measure soluble IL-7 receptor shows minimal impact of IL-7 treatment. J Immunol Methods. 2010;353(1-2): 115-23.

79. Crawley AM, Faucher S, Angel JB. Soluble IL-7R alpha (sCD127) inhibits IL-7 activity and is increased in HIV infection. J Immunol. 2010;184(9):4679-87.

80. Andersson A, Srivastava $M K$, Harris-White $M$, et al. Role of CXCR3 ligands in IL-7/IL-7R alpha-Fc-mediated antitumor activity in lung cancer. Clin Cancer Res. 2011;17(11):3660-72.

81. Boyman O, Ramsey C, Kim DM, Sprent J, Surh CD. IL-7/antiIL-7 mAb complexes restore $\mathrm{T}$ cell development and induce homeostatic T Cell expansion without lymphopenia. J Immunol. 2008;180(11):7265-75.

82. Lundstrom $W$, Highfill $S$, Walsh $S T$, et al. Soluble IL7R $\alpha$ potentiates IL-7 bioactivity and promotes autoimmunity. Proc Natl Acad Sci U S A. 2013;110(19):E1761-70. 